\title{
Prediction methods of liquefaction phenomenon and mitigation strategies
}

\author{
William Araujo, Eng ${ }^{1}$, Jonathan Palinginis ${ }^{2}$, and Gaby Ruiz, Mgtr ${ }^{3}$ \\ ${ }^{1}$ University of Piura, Peru, william.araujo@udep.pe \\ ${ }^{2}$ Engineering Bachelor, Peru, palinginis.jonathan@gmail.com \\ ${ }^{3}$ University of Piura, Peru, gaby.ruiz@udep.pe
}

\begin{abstract}
The main objective of this research is to present a review about methods of analysis and mitigation in soil liquefaction, especially in those of sandy and loose density soils. The experience of different researchers shows that the most suitable methods of analysis are those that are based on "in situ" tests data while preserving the soil properties, especially those based on the use of SPT (Standard Penetration Test) because of the greatest existing data. Likewise, the most suitable mitigation methods is using gravel drains due to several advantages that improve liquation resistance, increasing the densification of soil, improving the drainage (quickly dissipates the interstitial pressures in an earthquake) and reduces cyclical tangential stress (which contributes to liquefaction) due to flexibility of the gravel pack.

Keywords - liquefaction, mitigation, SPT.
\end{abstract}

\section{INTRODUCTION}

Soil characteristics have an important role in the superstructure behavior. In a soil mechanics report, the main goal is to understand physical and geotechnical properties of the soil as well as the possible risks to external forces in interaction with it.

One of the main risks in low densified sandy soils with the presence of water and an external force such as the earthquake is the generation of liquefaction. This phenomenon was studied for the first time in 1964 after the earthquake in Niigata, Japan. Economical damage caused in repairs and reconstruction, as well as loss of human life motivated starting to research the phenomenon of soil liquefaction [1].

This phenomenon is not yet known clearly. Unless it is related to seismic conditions and to loose sandy soils, it also appeared in static states and also in another soils as gravels [2] and silts [3].

All the research reveals that the liquefaction occurs in the same area where there was liquefaction in the past. In addition, the standard penetration test [4-7] is the most usual method to analyze liquefaction risk due to the abundant data to correlate $\mathrm{N}$ value with other parameters such as the shear resistance of the soil. Likewise, there are numerous techniques of pre- and post-evaluation to improve the properties of the soil (density, drainage and resistance) and reduce the risk of damage to the construction [8-11].

\section{LIQUEFACTION MECHANISMS}

Due to the complexity of the liquefaction phenomenon and evidences of it, the common characteristics registers are based on seismic, geological, geotechnical considerations and phreatic level of the affected area [11].

\section{A. Seismic conditions}

In the case of dynamic liquefaction, the evidence shows that earthquakes liquefied areas on the coast and north-east [11]. Thus, it must be important to know: intensity, magnitude and duration of seismic movement.

According to the intensity and magnitude of the earthquake will be the magnitude of the induced stresses and deformations to the soil. These will depend on the hypocentral distance and the propagation of shear waves through the soil skeleton.

The duration of an earthquake could be very short but event very strong. Then, the dissipation of the pore pressure in the granular soil is not allowed, causing an undrained condition where the excess pore pressure surpasses the total stress, generating a zero total stress condition [12].

Several authors have correlated the distance between the epicenter zone and the area far from liquefaction with the magnitude of the earthquake that generated it with data from cases occurred in Japan between 1885 and 1990 [13-15]. They proposed an equation to calculate the lateral displacements induced by liquefaction as a function of seismic parameters, soil and geometric factors [13].

\section{B. Geological and geotechnical conditions}

The most susceptible soils to liquefying are saturated sediments of Holocene, river channels, alluvial soils, wind deposits and poorly compacted fill [13-14].

Geological conditions: The environments of young deposits (Holocene) and the age of the deposit contribute to the liquefaction [13-14]. The uniform granulometry and deposits in loose state as the fluvial and wind one are prone to liquefy when being saturated [12].

Granulometric conditions: A uniform or poorly graded granulometry as poorly graded sands will induce liquefaction due to their lower permeability. There will be a greater probability of this phenomenon when the coefficient of uniformity is greater than or equal to 2 [11].

Different researchers $[13,16]$ proposed different granulometric limits. Research on liquefaction have mostly focused on uniform clean sands, containing little or no fines (Fig. 1), besides content of fines increase liquefaction resistance [12]. 
In the earthquake of Wenchua, China $(\mathrm{Ms}=8, \mathrm{Mw}=9)$, sandy gravelly soils liquefied. These had a grain size between $1 \mathrm{~mm}$ to $30 \mathrm{~mm}[2]$.

The parameters found for a silty soil have been: Clay content $(<0.005 \mathrm{~mm})$ less to $15 \%$, liquid limit (LL) less than $35 \%$ and water content greater than $0.9 *$ LL. Some historical cases of silty soils with low clay content $(10 \%)$ have been susceptible to liquefaction [3]. A summary of geotechnical conditions in soils prone to liquefy is showed in this paper (Table I). Also a relationship between the fines content of the liquefied soils and the maximum settlement is showed from five cities. The settlement of buildings decreased with fines content (Fig. 2).

\section{Phreatic Napa}

The effects of liquefaction are commonly observed in places where phreatic napa is a few meters below ground surface. In all cases, a phreatic Napa is needed to generated liquefaction $[11,17]$.

\section{Confinement Pressure}

The confinement pressure is another important consideration for the development of the phenomenon of liquefaction. If the confinement pressure is low (layers close to the surface of the ground), liquefaction can occurs [18].

\section{E. Shear Stress}

So far, processes of shear states that generate liquefaction have only been studied in saturated sandy soils. [18] When loose and saturated sand is subjected to shear stresses, it undergoes a process of contractive deformation (its volume is reduced, experiencing large deformations) and pore pressure increases, causing the soil effective stress to be zero.

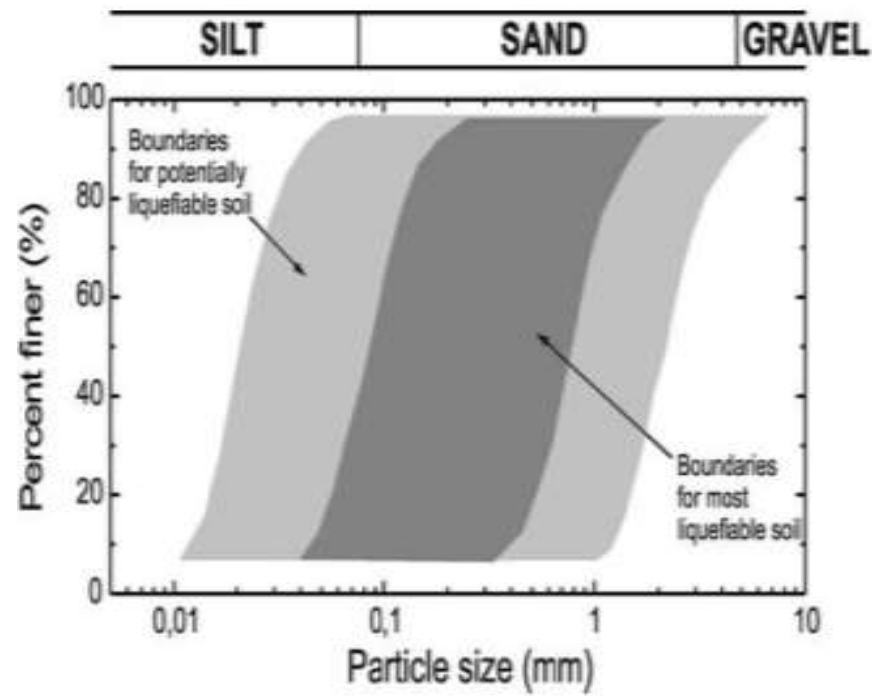

Fig. 1. Granulometric limits in sandy soils [12].

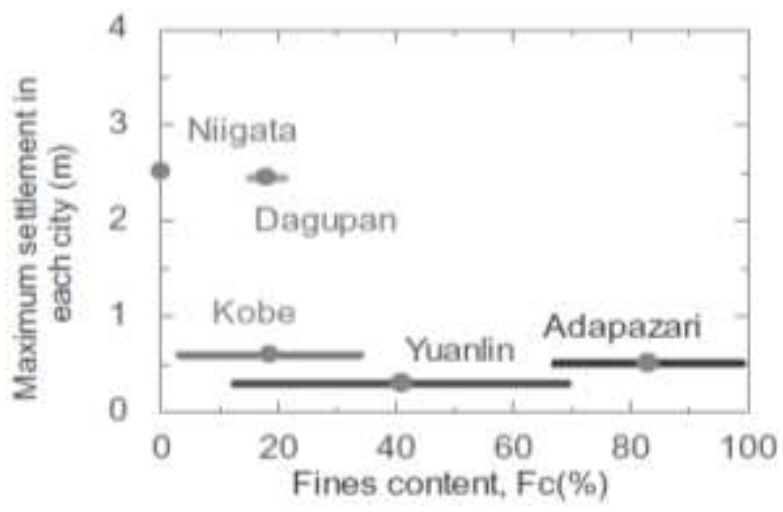

Fig. 2. Relationship between fines content and maximum settlement from 5 sities [17].

\section{METHODS OF LIQUEFACTION ANALYSIS}

The goal of the liquefaction analysis methods is the quantitatively or qualitatively measurement of the liquefaction potential of a site.

A. With the use of laboratory tests: Undrained consolidated triaxial test (UC): This test is the most usual laboratory method to detect liquefaction. The pore pressure is measured in order to determine the parameters of cohesion (c) and angle of friction $(\varphi)$ in terms of total and effective stress to draw trajectories of q-p ', e-p' and others. In a trajectory q-p' for a loose material, different states are observed: critical state (CS), phase transformation state (PTS), quasistable state (QSS) and unstable instable state (UIS). In the e-p trajectory, it is possible to evaluate the critical state line (CSL) and the phase transformation line (PTL), which depend on the confinement of the sample in the failure stage [17].

In 1996 was proposed a method with the location of the steady state line and the consolidation curves for dense and loose state [17]. Two zones are defined: the contractant (Ac) and the dilatant (Ad). To determine the liquefaction potential of a soil (PL), the area of the dilating zone and the contractive zone is determined by the expression of equation 1 . In this way, as Ac increases, vulnerability to liquefaction is greater (Fig. 3).

TABLE I

GEOTECHNICAL CONDITIONS IN LIQUEFIABLE SOILS.

\begin{tabular}{|c|c|c|c|c|c|}
\hline Soil Type & $\begin{array}{c}\text { Fine } \\
\text { content }\end{array}$ & $\begin{array}{c}\mathrm{N} \text { from } \\
\text { SPT }^{\mathrm{a}}\end{array}$ & $\begin{array}{c}\text { Clay } \\
\text { content }\end{array}$ & $\begin{array}{c}\text { Liquid } \\
\text { limit }\end{array}$ & $\begin{array}{c}\text { Grain } \\
\text { size }\end{array}$ \\
\hline $\begin{array}{l}\text { Poorly } \\
\text { graded } \\
\text { sand }\end{array}$ & $\begin{array}{c}<10 \% \\
{[20]} \\
=40 \% \\
{[20]}\end{array}$ & $\begin{array}{c}<25 \\
{[19]}\end{array}$ & - & - & $\begin{array}{c}0.02- \\
0.1 \mathrm{~mm} \\
{[4,15]}\end{array}$ \\
\hline Silt & - & - & $\begin{array}{c}<10 \% \\
{[3]}\end{array}$ & $\begin{array}{c}<35 \% \\
{[3]}\end{array}$ & - \\
\hline Gravel & - & - & - & - & $\begin{array}{c}2-63 \\
\mathrm{~mm}[2]\end{array}$ \\
\hline
\end{tabular}

${ }^{\text {aStandard Penetration Test }}$

16 $^{\text {th }}$ LACCEI International Multi-Conference for Engineering, Education, and Technology: "Innovation in Education and Inclusion", 19-21 July 2018, Lima, United States. 


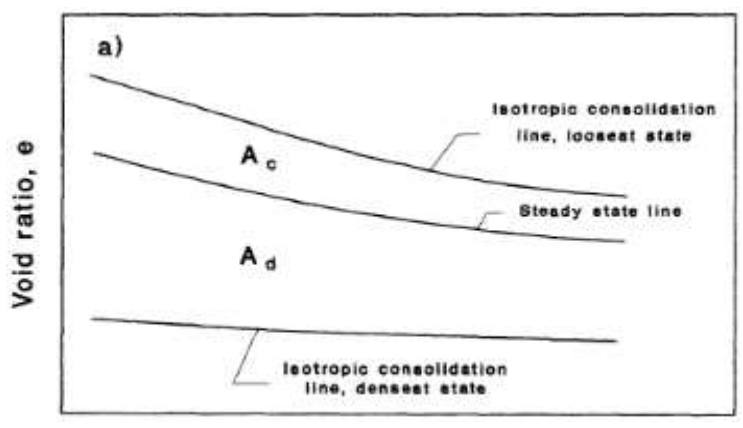

Effective mean stress, $p^{\prime}$

Fig. 3. Contractant and dilatant zone in liquefaction soils [21].

\section{B. With the use of "in situ” tests}

Standard penetration test (SPT): The most accepted field method to evaluate susceptibility to liquefaction is the Standard Penetration Test (SPT). Many researchers have proposed methodologies using correlations with SPT $[4,5,15]$.

Seed and Idriss, 1971: These authors proposed a simplified semi-empirical procedure for the determination of the susceptibility to the phenomenon of liquefaction in saturated loose sands. It is based on observation and recording of cases where this phenomenon has occurred, in addition to the evaluation of the results of standard penetration tests (SPT) and shear stresses induced in soil during a seismic event. This method consists in finding a safety factor $\left(\mathrm{F}_{\mathrm{Lsi}}\right)$. Soil strata that have $\mathrm{F}_{\mathrm{Lsi}}<1$ are liquefiable.

The liquefaction safety factor is a function of cyclical stress ratio (CSR) and average cyclical stress. In order to calculate the CSR, [15] separate two groups of soils for $\mathrm{N}>23.5$ and for $\mathrm{N}$ $<23.5$.

Initially, was proposed their formulation for clean sand cases [15]. However, the resistance to liquefaction in silty sands was underestimated so $\mathrm{N}$ value of the SPT had to be corrected.

According to [7] was validated three methodologies of liquation analysis that use the $\mathrm{N}$ value of SPT $[3,4,15]$ ) for soils Moyobamba, Peru in a work for CISMID applying an earthquake of $0.20 \mathrm{~g}$ and $\mathrm{Mw}$ of 7.2 for groundwater levels of $1.70 \mathrm{~m}$ and $2.40 \mathrm{~m}$, obtaining similar values of the liquefaction resistance factor in each method.

Iwasaki y Tatsuoka, 1979: These researchers propose an equation with a parameter called liquefaction potential index (PL), which represents the extent and damage of liquefaction.

The liquefaction potential index is expressed in terms of cyclical stress ratio (CSR). Which, unlike [15], has a logarithmic form to figure using the $\mathrm{N}$ value of SPT for soils with D50 (sieve diameter through which $50 \%$ of the soil passes) between 0.02 and $0.6 \mathrm{~mm}$.

Tokimatsu and Yoshimi, 1983: This method calculates a resistance to liquefaction (CRR) in sand soils, through an expression that incorporates a corrective coefficient based on the magnitude of a seismic event into the calculation of cyclic stress ratio (CSR). They propose a graph that correlates the $\mathrm{N}$ corrected value of SPT with the value of the CSR for values of shear deformation of 2, 5 and 10\% (Fig. 4).

Shear Wave Velocity (Vs): proposed a procedure to evaluate the liquefaction potential, based on the SPT test, according to the simplified [15] and in the measurement of the cutting wave velocity (Vs). The advantage of $\mathrm{Vs}$ is that it is applicable in sites with uncontrolled sanitary landfills and gravel deposits where it is not possible to apply SPT or CPT [22]. However, this method alone is not reliable [23].

Dynamic Penetration Test (DPT): This test allows measurement and analysis of the resistance of the different strata of a soil before the possible risks of liquefaction through correlations and probabilistic methods. This method has many advantages: low economic cost, easy execution, data and codes available for verification of correlations, simple interpretation of results and relatively short application time. The advantage of DPT over other in situ tests is that it can be used in gravel soils [2]. The Earthquake Administration, Institute of Mechanical Engineering of China, made a detailed study of the soil of the areas where liquefaction occurred during the earthquake in Wenchuan, China [2]. The investigation concluded that the results and correlations (Fig. 5) in the application of the Chinese Dynamic Penetration Test, the equation used in the adjustment of the data is valid for the study and prediction of the liquefaction phenomenon in China, but it is also possible to adapt the method to soils with the same conditions in other parts of the world.

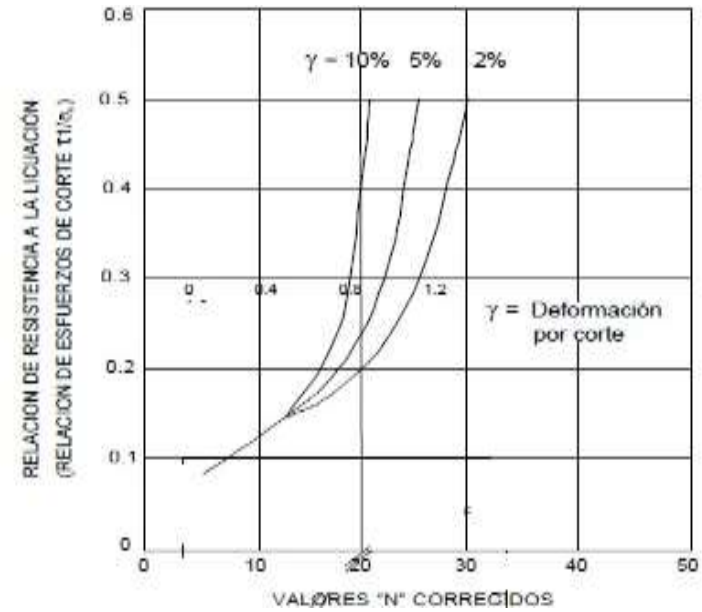

Fig. 4. Relationship of the Resistance to the Liquefaction vs. Values N Corrected [5].

16 $^{\text {th }}$ LACCEI International Multi-Conference for Engineering, Education, and Technology: "Innovation in Education and Inclusion", 19-21 July 2018, Lima, United States. 


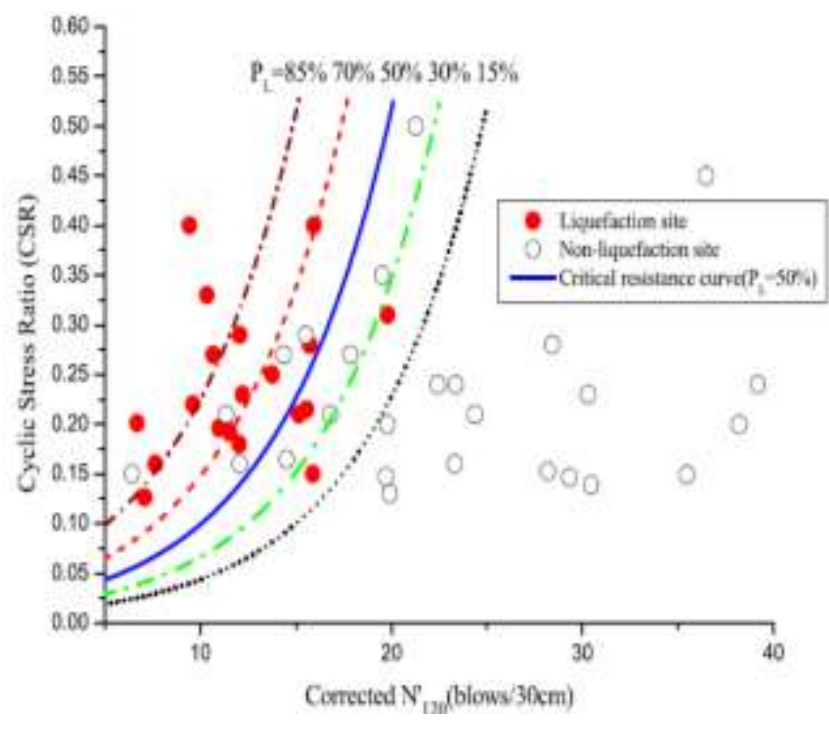

Fig. 5. Liquefaction probability curves in gravelly chinese soils [2].

Cone Penetration Test (CPT): explain a probabilistic method that evaluates the liquefaction induced by a penetration cone tests (CPT) in non-cohesive soils. This probabilistic relation was developed using a maximum likelihood method. The CSR is calculated based on the resistance to penetration $\left(q_{c 1 N}\right)$ obtained from the CPT test [6].

According to [22] each in situ test has advantages and disadvantages (Table II).

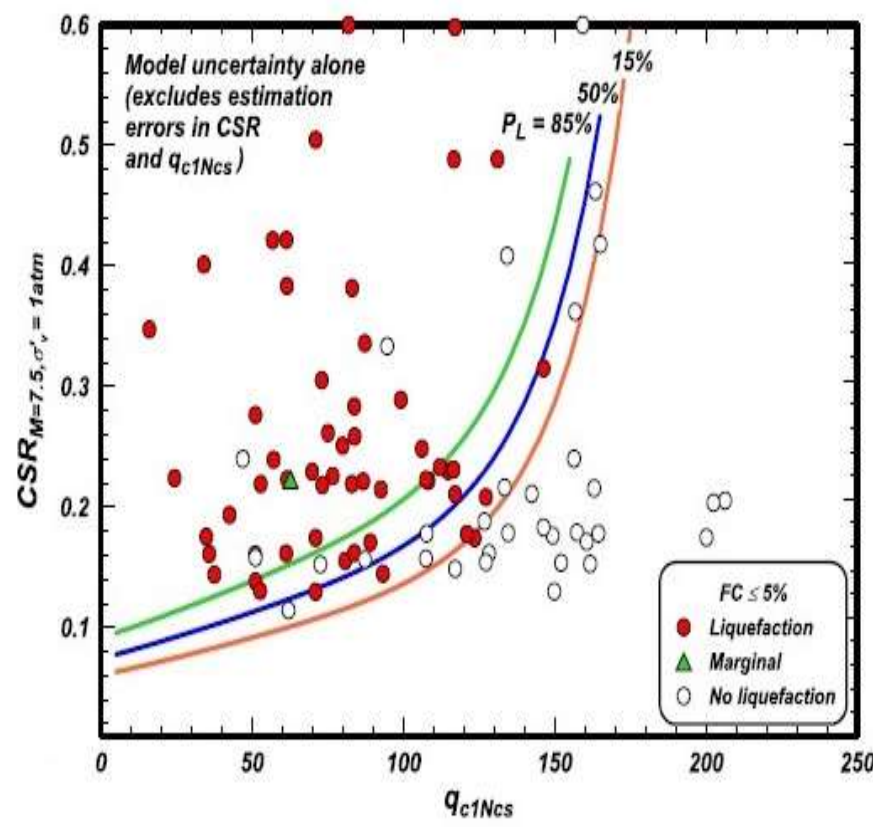

Fig. 6. Curves of $C S R$ vs $q_{c 1 N}$ for probabilities of liquefaction of 15,50 and $85 \%$ in clean sands [24].
TABLE II

COMPARISON OF DIFFERENT IN SITU TESTS [22].

\begin{tabular}{|c|c|c|}
\hline In situ test & Advantage & Disadvantage \\
\hline SPT & $\begin{array}{l}\text { Records of more years of } \\
\text { experience. } \\
\text { It extracts altered and } \\
\text { representative samples of } \\
\text { soil. } \\
\text { Useful in soil without } \\
\text { gravel. }\end{array}$ & $\begin{array}{l}\text { It is not applicable in gravel } \\
\text { soil. }\end{array}$ \\
\hline CPT & $\begin{array}{l}\text { It gives more detailed } \\
\text { stratigraphy of the soil. } \\
\text { More reliable liquefaction } \\
\text { resistance ratio curve } \\
\text { (CRR). } \\
\text { Useful in soils without } \\
\text { gravel }\end{array}$ & $\begin{array}{l}\text { Por si solo no tiene validez } \\
\text { debe acompañarse de } \\
\text { muestreos del suelo para } \\
\text { identificarlo ya ue no es un } \\
\text { ensayo ue extraiga muestras. } \\
\text { No muestrea el suelo. }\end{array}$ \\
\hline Vs & $\begin{array}{l}\text { Applicable in sites with } \\
\text { uncontrolled sanitary } \\
\text { landfills and gravel deposits } \\
\text { where it is not possible to } \\
\text { apply SPT or CPT. } \\
\text { Applicable to all types of } \\
\text { soil. }\end{array}$ & $\begin{array}{l}\text { By itself it is not reliable. } \\
\text { Do not extract samples from } \\
\text { the soil. }\end{array}$ \\
\hline DPT & Useful in gravel soil. & Few measurements. \\
\hline
\end{tabular}

\section{METHODS OF LIQUEFACTION MITIGATION}

A. Gravel drains: Gravel drainage techniques were first proposed by $[25,31]$ studied the drainage in columns of gravel of $12 \mathrm{~m}$ long and $0.6 \mathrm{~m}$ diameter installed in the center of a pile in loose sand. He confirmed that zones with greater densification drain better before earthquake, mitigating the liquefaction. [28] found that the installation of gravel drains (Fig. 8) by vibro-replacement mitigates the liquefaction potential by increasing the density of the soil, controlling the drainage and reducing the pore pressure. According to [28], the risk of liquefaction and soil deformations nowadays are reduced very effectively with these methods.

B. Gravel drains encased with geosynthetics: modeled the mitigation of strata of saturated sand using columns of gravels encased with geosynthetics, using 3D finite elements. They found that even when the columns do not mitigates the liquefaction, reduce effectively the displacements and do not generate permanent deformations on the soil [31].

$C$ Reinforcement and expansion of the damaged foundation: In 2007 , after the effects of an earthquake of $8 \mathrm{Mw}$ and a peak acceleration of $0.48 \mathrm{~g}$ in Tambo de Mora-Pisco, Peru, it was necessary to increase support area of the foundation (Fig. 7), in order that the pressure applied is at least equal to the current load capacity of soil. Field tests in industrial zones was used to detect admissible pressure at the foundation level $(0.43$ $\mathrm{Kg} / \mathrm{cm}^{2}$ ), which was lower than the requested pressure of 0.85 $\mathrm{Kg} / \mathrm{cm}^{2}[25]$.

16 $^{\text {th }}$ LACCEI International Multi-Conference for Engineering, Education, and Technology: "Innovation in Education and 


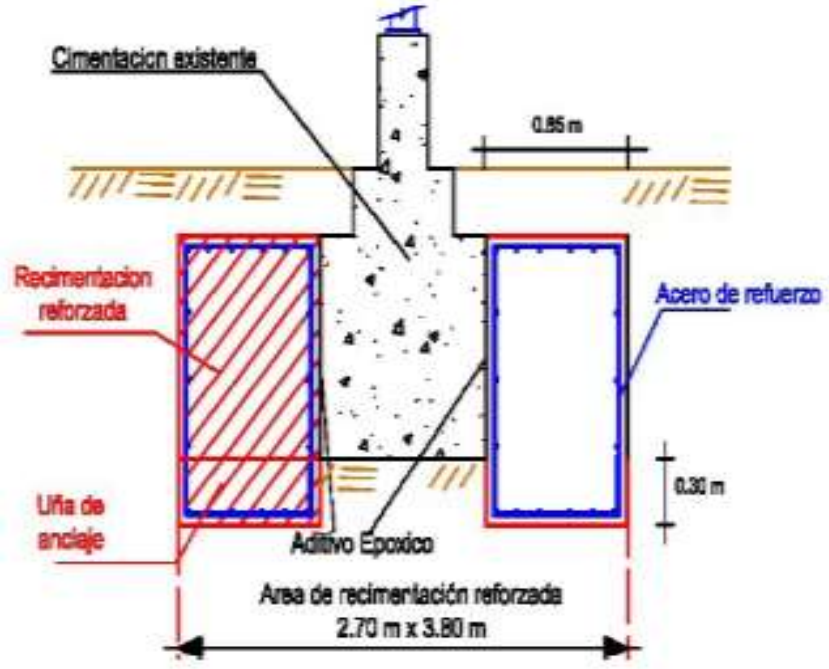

Fig. 7. Increase of the support area of the foundation of a cooler in order to increase the allowable support capacity [25].

D. Silica injection using curved grouted penetration technique (PGM): According to [32] this method consists in the injection of chemical products to improve liquefiable soils (Fig. $9,10)$. The PGM was initially a vertical drilling method (Fig. 12) over the zone of the liquefiable soil. However, this can create a problem when there are structures that must be kept in use and operation during the intervention.

The demands of achieving a rapid and undisturbed advance of operations such as those of an airport, the methodology was improved to a controlled curved drilling. Since 1999, 210 projects have been successfully executed using this methodology [33]. Silica and air is injected replacing the porosity of the soil and reducing the properties of permeability [33-34].

This method was implemented to improve the liquefaction resistance of the soil in the Tokyo International Airport after an earthquake had occurred in the area. The chemicals were injected through the vertical holes by means of injection tubes. 270 curved penetrations of $150 \mathrm{~m}$ maximum length and a total of $12400 \mathrm{~m} 3$ of silica were made. At the end of the work, the unconfined compression effort was verified to be above 80 $\mathrm{kN} / \mathrm{m}^{2}$ and that the soil would not liquefy with a strong earthquake.
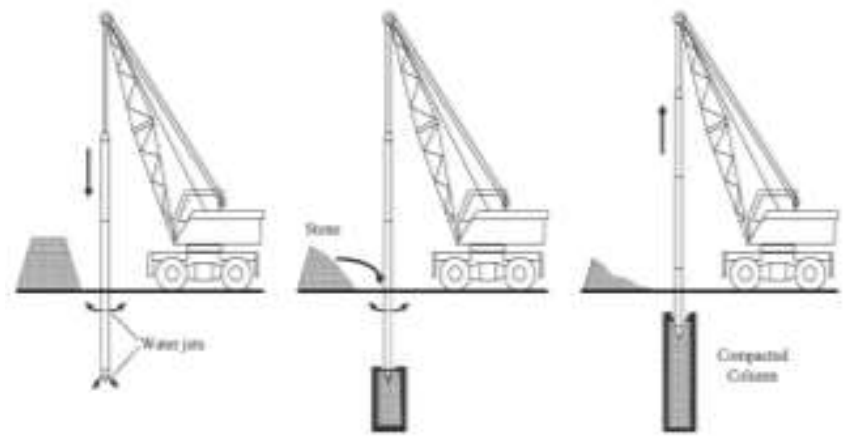

Fig. 8. Construction of gravel drain by vibro-replacement [30].

E. Use of polypropylene fibers as a stabilizer: According to [35] several studies have been conducted with random distributions of polypropylene fibers as reinforcement in specimens of soil to reduce liquefaction and lateral expansion. This method does not increase the compression or tension strength of the soil but there is a better stability of the soil mass. The shear resistance improves with the addition of polypropylene fibers. From $0.8 \%$ of added content in the specimens, the pore pressure has a non-linear behavior as a function of the lateral displacement which in a real structure could cause differential settlements [35].

F. Air injection to reduce deformation under surface foundations: This method is considered reliable and of an effective cost-benefit, in addition to being ecological in comparison with others. It is based on the saturation degree of the soil. By reducing the degree of saturation of the soil $(\mathrm{Sr})$, the potential to liquefy is also reduced [36]. The $S r$ can be attributed to the presence of air bubbles retained in the voids of the soil, as well as the dissipation of the pore pressure. The reduction is achieved by the introduction of artificial air for a long period of time in which the air bubbles are easily dissipated. [36] tried to reduce the degree of saturation of the soil through the injection of air. Centrifugal dynamics was used for the injection of air found that this injection reduces the deformations of the soil and the average settlements [34].

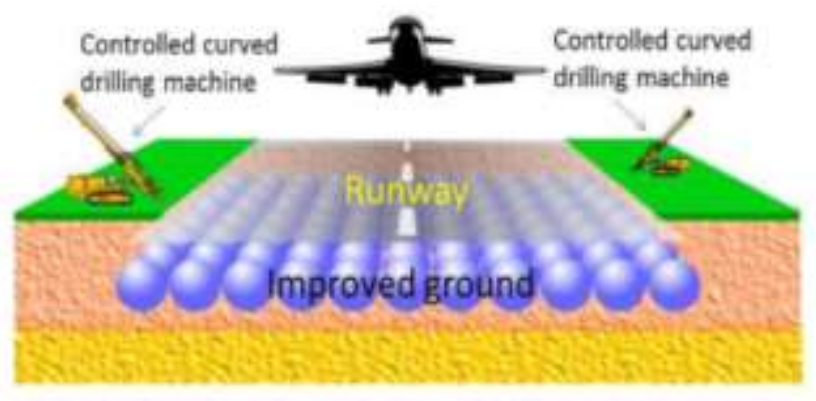

Fig. 9. Schematic representation of curved penetration under the runway of Tokyo International Airport during the operation [32].

$1^{\text {th }}$ LACCEI International Multi-Conference for Engineering, Education, and Technology: "Innovation in Education and Inclusion", 19-21 July 2018, Lima, United States. 


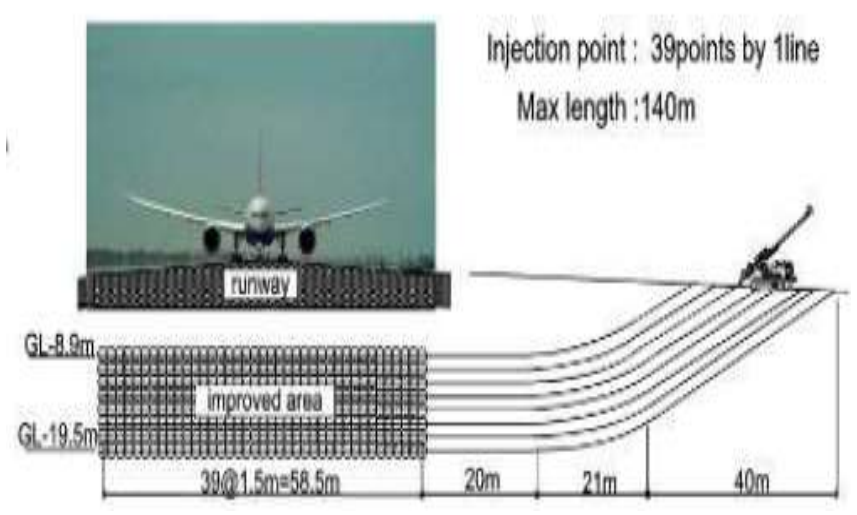

Fig. 10. Cross section of the penetration line on the runway of Tokyo International Airport [32].

G. Dynamic compaction: According to [7] massive dynamic compaction has the disadvantage of generating noise and not availability of equipment. However it can be replaced by smooth roller compaction whose advantage would be a lower cost and availability of different sizes of equipment and compaction energy. Its disadvantage would be that the depth of influence is limited [23]. Table III shows a comparison of advantages and disadvantages of different liquefaction mitigation strategy.

TABLE III

COMPARISON OF DIFFERENT LIQUEFACTION MITIGATION STRATEGIES

\begin{tabular}{|c|c|c|}
\hline Mitigation Strategy & Advantage & Disadvantage \\
\hline Gravel drains & $\begin{array}{l}\text { Densifies the soil when } \\
\text { installed } \\
\text { vibroreplacement. } \\
\text { It generates drainage } \\
\text { dissipating the pore } \\
\text { pressure. } \\
\text { It reduces the cyclical } \\
\text { tangential stress that } \\
\text { generates the soil when } \\
\text { liquefying. } \\
\text { Reduces vertical } \\
\text { deformations of the soil. } \\
\text { The settlements are } \\
\text { reduced to } 50 \% \text { [37]. } \\
\text { Simplicity in its } \\
\text { constructive process. A } 20 \\
\text { m gravel column runs } \\
\text { approximately one hour } \\
\text { [38]. }\end{array}$ & $\begin{array}{l}\text { The soil can not have } \\
\text { more than } 2 \% \text { clay } \\
\text { otherwise it does not } \\
\text { densify well in } \\
\text { vibration method } \\
\text { [39]. }\end{array}$ \\
\hline $\begin{array}{lr}\text { Gravel } & \text { drains } \\
\text { encased } & \text { with } \\
\text { geosynthetics: }\end{array}$ & $\begin{array}{l}\text { Reduction of lateral } \\
\text { deformation } \\
\text { It improves the rigidity of } \\
\text { the foundation without the } \\
\text { need to increase the } \\
\text { diameter of the gravel } \\
\text { [31]. }\end{array}$ & $\begin{array}{l}\text { Equal to drains with } \\
\text { gravel without } \\
\text { encased. } \\
\text { It has only been } \\
\text { modeled with finite } \\
\text { elements and } \\
\text { laboratory tests. }\end{array}$ \\
\hline
\end{tabular}

TABLE III (continued)

\begin{tabular}{|c|c|c|}
\hline $\begin{array}{c}\text { Mitigation } \\
\text { Strategy }\end{array}$ & Advantage & Disadvantage \\
\hline $\begin{array}{l}\text { Reinforcement and } \\
\text { expansion of the } \\
\text { damaged } \\
\text { foundation }\end{array}$ & $\begin{array}{l}\text { Decreases the stress } \\
\text { transmitted from the } \\
\text { structure to the soil. }\end{array}$ & $\begin{array}{l}\text { Stops the functioning of } \\
\text { the structure built to } \\
\text { improve its behavior. }\end{array}$ \\
\hline $\begin{array}{l}\text { Silica injection } \\
\text { using curved } \\
\text { grouted } \\
\text { penetration } \\
\text { technique (PGM): }\end{array}$ & $\begin{array}{l}\text { Technique non-stop } \\
\text { operation. } \\
\text { Significantly improve } \\
\text { resistance } \\
\text { liquefaction. } \\
\text { Reduces pore pressure. } \\
\text { The perforations can } \\
\text { reach up to } 200 \text { meters. } \\
\text { [37] }\end{array}$ & $\begin{array}{l}\text { It requires several curved } \\
\text { penetration machines. } \\
\text { It requires a } \\
\text { sophisticated planning to } \\
\text { avoid accidents when } \\
\text { treating a non-stop } \\
\text { technique without } \\
\text { disturbance of daily } \\
\text { activities [38]. } \\
\text { Reduces the properties of } \\
\text { permeability. } \\
\text { The time-gel of the silica } \\
\text { must be controlled so as } \\
\text { not to cause } \\
\text { sedimentation. } \\
\text { Not economic. }\end{array}$ \\
\hline $\begin{array}{ll}\text { Use } & \text { of } \\
\text { polypropylene } & \\
\text { fibers as a } \\
\text { stabilizer }\end{array}$ & $\begin{array}{l}\text { Generate stabilization of } \\
\text { the soil mass. } \\
\text { Improves the shear } \\
\text { resistance of the soil. }\end{array}$ & $\begin{array}{l}\text { Not economic } \\
\text { More than } 0.8 \% \text { of the } \\
\text { polypropylene fiber } \\
\text { content could generate } \\
\text { differential settlements } \\
\text { in the structure. }\end{array}$ \\
\hline $\begin{array}{l}\text { Air injection to } \\
\text { reduce } \\
\text { deformation under } \\
\text { surface } \\
\text { foundations }\end{array}$ & $\begin{array}{l}\text { Ecological. } \\
\text { Reliable [40]. Reduces } \\
\text { the degree of saturation } \\
\text { of the soil by reducing } \\
\text { the pore pressure. }\end{array}$ & $\begin{array}{l}\text { It has only been modeled } \\
\text { in centrifugal tests. }\end{array}$ \\
\hline $\begin{array}{l}\text { Dynamic } \\
\text { compaction }\end{array}$ & $\begin{array}{l}\text { Lower cost than other } \\
\text { methods. } \\
\text { It can be replaced by } \\
\text { roller compaction if } \\
\text { there are no equipment } \\
\text { available [25]. }\end{array}$ & $\begin{array}{l}\text { Noise generation } \\
\text { Limited thickness } \\
\text { influence [25]. }\end{array}$ \\
\hline
\end{tabular}

\section{CONCLUSIONS}

Literature review evidence that liquefaction could not only be presented in a dynamic but in a static event. A static condition by the action of the weight of the soil or the structure itself is possible. On the other hand, the liquefaction develops mainly in very loose sandy soils with fine contents lower than $5 \%$. However, recent research has shown that this phenomenon also applies to sandy gravels and silts.

The methods of liquefaction analysis based on the "in situ" tests have also better reliability due to the abundant correlated data and practicality. SPT is the most commonly used.

Different methods of mitigation of liquefaction in soils have been developed. Densification using gravel drains is still the most indicated solution due to practicality, low cost and availability of equipment, as well as the implications that it generates in the improvement of the resistance, behavior as drain and densification of the soil. New methods required to be developed that assure to keep in operation the structures over the soils during the interventions.

16 $^{\text {th }}$ LACCEI International Multi-Conference for Engineering, Education, and Technology: "Innovation in Education and 


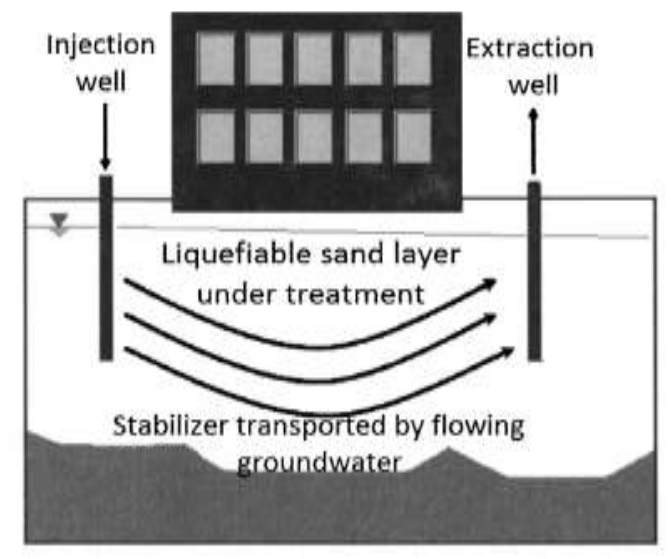

Fig. 11. Liquefaction mitigation with vertical penetration method with grouting with silica injection as a stabilizer [33].

\section{REFERENCES}

[1] National Research Council (US), Committee on Earthquake Engineering Research. "Liquefaction of soils during earthquakes", National Academies, Washington, D.C., 1985.

[2] Z. Cao, L. Youd and X. Yuan. "Chinese Dynamic Penetration Test for Liquefaction Evaluation in Gravelly Soils". Journal Geotechnical Geoenvironmental Engineering, vol. 139, pp. 1320-1333, 2013.

[3] D. Andrews and G. Martin. "Criteria for liquefaction of silty soil". 12th World Conference on Earthquake Engineering New Zeeland 2000, 2000.

[4] H. Seed. "Soil liquefaction and cyclic mobility evaluation for level ground during earthquakes". Journal Geotechnical Engineering Division. ASCE, vol. 105,no. GT2, pp. 201-255, 1979.

[5] K, Tokimatsu Y. Yoshimi, K. Ariizumi.. "Evaluation of liquefaction resistance of sand improved by deep vibratory compactions". Soils, vol. 30, pp. 153-8, 1990.

[6] R. Boulanger and M. Idriss. "CPT based liquefaction triggering procedure". Journal of Geotechnical and Geoenvironmental Engineering, vol. 142, pp. 1943-5606, 2016.

[7] A. Carrillo and L. Alcayhuaman. "Licuación de Suelos durante el sismo Pisco-Perú-2007". Sixth LACCEI International Latin American and Caribbean Conference for Engineering and Technology (Partnering to success: engineering. Education. Research and Development. Tegucigalpa, Honduras, 2007.

[8] K. Adalier, A. Elgamal., J. Meneses and I Baez. Stone column as liquefaction counter-measure in non-plastic silty soils. Journal of Soil Dynamics and Earthquake Engineering, vol. 23, no. 7, pp. 571- 584, 2003.

[9] S. Takano, K. Hayashi, K. Zen and R. Rasouli. "Controlled curved drilling technique in the permeation grouting method for improvement works of and airport in operation". Advances in Transportation Geotechnics, vol 143, pp. 539-547, 2016.

[10]Rasouli, R., et al. "Controlled permeation grouting method for mitigation of liquefaction". Journal of Geotechnical and Geoenvironmental Engineering, vol. 11, pp.1943-5606, 2016.

[11]R. Ayala. "Evaluación del potencial de licuación de suelos en la ciudad de Tambo de Mora". Thesis. National University of Engineering, Lima, Peru, 2010.

[12]H. Tsuchida. "Prediction and countermeasure against the liquefaction in sand deposits".Seminar in the Port and Harbor Research Institute, 3.1-3.33, 1970.

[13]L. Youd. "Mapping of earthquake-induced liquefaction for seismic zonation". Proc., Fourth International Conference on Seismic Zonation, vol. 1, pp. $111-147,1991$.

[14]E. Krinitzsky and M. Hynes. "The Bhuj, India, Earthquake: lessons learned for earthquake safety of dams on alluvium". Engineering Geology vol. 66, no. 3- 4, pp. 163- 196, 2002.

[15]L. Seed and M. Idriss. "Analysis of the soil liquefaction in Niigata earthquake". Proceedings ASCE, 1967.
[16]P. Henríquez. "Mejora de terrenos potencialmente licuables con inyecciones de compactación". Thesis Dissertation $(\mathrm{PhD})$. Polytechnic University of Madrid. Spain, 2007.

[17]S. Yasuda. "Damage to structures due to soil liquefaction". Tokyo, Japan. 2010 Taylor \& Francis Group, London, ISBN 978-0-415-60034-7, 2010.

[18]A. Leoni. "Procesos de licuación del suelo". Cátedra de Geotecnia III. Universidad Nacional de la Plata. Buenos Aires, Argentina, 2004.

[19]K, Tokimatsu Y. Yoshimi, K. Ariizumi. "Empirical correlation of liquefaction based on SPT N-value and fines content". Soils and Foundations. Japanese Society of Soil Mechanics and Foundation Engineering, vol. 23, no. 4, pp. 56-74, 1983.

[20]A. Numata, and Mori S. "Limits in the gradation curves of liquefiable soils". $13^{\text {th }}$ world conference on earthquake engineering. Vancouver, B.C., Canada. Paper n ${ }^{\circ} 1190,2004$.

[21]R. Verdugo and K. Ishihara. "The steady state of sandy soils". Soils and foundations, vol 36. pp 81-91, 1996.

[22]L Youd. and M. Idriss. "Liquefaction resistance of soils: Summary report from the 1996 NCEER and 1998 NCEER/NSF workshop on evaluation of liquefaction resistance of soils". Journal of Geotechnical and Geoenvironmental Engineering, ASCE, vol. 127, no. 10, pp. 817-833, 2001.

[23]R. Andrus, H Stokoe, and C. Hsein. "Guide for Shear-Wave-Based Liquefaction Potential Evaluation”. Earthquake Spectra: May 2004, vol. 20, no. 2, pp. 285-308, 2004

[24]R. Boulanger and M. Idriss. "Liquefaction susceptibility criteria for silts and clays". Journal of Geotechnical and Geoenvironmental Engineering, vol. 11, pp. 1413-1426, 2006.

[25]K. Adalier. And A. Elgamal. "Mitigation of liquefaction and associated ground deformations by stone columns". Engineering Geology, vol. 72, pp. 275-291, 2004.

[26]H. Seed. "Soil liquefaction and cyclic mobility evaluation for level ground during earthquakes". Journal Geotechnical Engineering Division. ASCE. vol. 105, No. GT2, pp. 201-255, 1977.

[27]A. Carrillo and L. Alcayhuaman. "Licuación de Suelos durante el sismo Pisco-Perú-2007". Sixth LACCEI International Latin American and Caribbean Conference for Engineering and Technology Partnering to success: engineering. Education. Research and Development. Tugucigalpa, Honduras. 2007.

[28]H. Priebe. "The prevention of liquefaction by vibro-replacement". Proc., Earthquake Resistance Construction and Design, Berlin, Germany, 1989.

[29]S. Iai. "Large scale model tests and analysis of gravel drains". Report of Port and Harbor Research Institute English Edition, 1988.

[30]K. Adalier, A. Elgamal, J. Meneses and I. Baez. "Stone column as liquefaction counter-measure in non-plastic silty soils". Journal of Soil Dynamics and Earthquake Engineering, vol. 23, no. 7, pp. 571- 584, 2003.

[31]L. Tang, S. Cong, X. Ling, J. Lu and A. Elgamal. "Numerical study on ground improvement for liquefaction mitigation using stone columns encased with geosynthetics", Geotextiles and Geomembranes, 2015.

[32]S. Takano, K. Hayashi, K. Zen and R. Rasoulli. "Controlled curved drilling technique in the permeation grouting method for improvement works of and airport in operation". Advances in Transportation Geotechnics, 143. pp. 539-547, 2016.

[33]R. Rasouli, K. Hayashi and H. Zen. "Controlled permeation grouting method for mitigation of liquefaction". Journal of Geotechnical and Geoenvironmental Engineering, vol. 11, pp. 1943-5606, 2016.

[34]A. Zeybek. "Physical modelling of air injection to remediate liquefaction". International Journal of Physical Modelling in Geotechnics, pp. 1-13, 2017.

[35]M. Muhammad, A. Namdar and I. Zakaria. "Liquefaction Mechanisms and Mitigation - A review". Research Journal of Applied Sciences, Technology, vol. 5, no. 2, pp. 574-578, 2003.

[36]K. Adalier and A. Elgamal "Mitigation of liquefaction and associated ground deformations by stone columns". Engineering Geology, vol. 72, pp. 275-291, 2004.

[37]A. Saito, K. Taghawa, T. Tamura, H. Oishi, H. Nagayama and H. Shimaoka, "A countermeasure for sand liquefaction: gravel drain method". Nippon Kokan Technical Report, Overseas, no. 51, Japan, 1987.

[38]J. Baez and G. Martin, "Permeability and shear wave velocity of vibroreplacement stone columns. Soil Improvement for Earthquake Hazard

$1^{\text {th }}$ LACCEI International Multi-Conference for Engineering, Education, and Technology: "Innovation in Education and Inclusion", 19-21 July 2018, Lima, United States. 
Mitigation". ASCE Geotechnical Special Publication, vol. 49, pp. 66-81. New York, NY, 1995.

[39]A. Zeybek and G. Phani. "Physical modelling of air injection to remediate liquefaction". International Journal of Physical Modelling in Geotechnics, pp. 621-638, 2017.

16 $^{\text {th }}$ LACCEI International Multi-Conference for Engineering, Education, and Technology: "Innovation in Education and Inclusion", 19-21 July 2018, Lima, United States. 